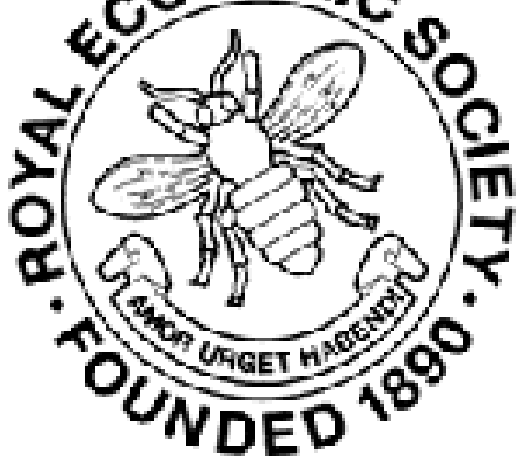

\title{
Review
}

\section{Author(s): Hartley Withers}

Review by: Hartley Withers

Source: The Economic Journal, Vol. 27, No. 107 (Sep., 1917), pp. 367-372

Published by: Wiley on behalf of the Royal Economic Society

Stable URL: http://www.jstor.org/stable/2222296

Accessed: 27-06-2016 03:30 UTC

Your use of the JSTOR archive indicates your acceptance of the Terms \& Conditions of Use, available at

http://about.jstor.org/terms

JSTOR is a not-for-profit service that helps scholars, researchers, and students discover, use, and build upon a wide range of content in a trusted digital archive. We use information technology and tools to increase productivity and facilitate new forms of scholarship. For more information about JSTOR, please contact support@jstor.org.

Royal Economic Society, Wiley are collaborating with JSTOR to digitize, preserve and extend access to The Economic Journal 
The Mechanism of Exchange: A Handbook of Currency, Banking and Trade in Peace and in War. By JoHN A. TODD, B.L., Professor of Economics and Commerce, University College, Nottingham, etc. (Oxford University Press. 1917. Pp. ix +255 . Price 5s. net.)

"Economics," says Prof. Todd in his cheery and stimulating preface, "has come into its own" as a result of the war. It is a bold and rather paradoxical view, at a time when most of what the plain man believed to be the laws of what he had been taught to regard as economic science have been overruled by bureaucratic fiat-when the supply of most things is controlled and the demand for many is regulated, when capital is not allowed to leave the country or be put into home industry without Treasury sanction, and the mobility of labour is severely restricted. But the Professor is seen to be right as soon as we give a wide enough meaning to the word Economics. The result of the war, as he truly says, was "a striking revival of interest in economic problems; and questions of currency, banking and trade naturally attracted the greatest attention because they were the first to be affected by the convulsion. Business men of all kinds, finding their business paralysed by the breakdown of the usual monetary and financial facilities, wanted to know why, and they found that the answer lay with the economists." Whether many business men would agree with the claim put forward in these last words, I am rather inclined to doubt. Some of them might maliciously rake up economic prophecies made at the beginning of the war to the effect that it could not last more than a few months because of the financial exhaustion that war on a modern scale would inevitably produce, and might also ask who was responsible for the view that unemployment on an appalling scale was likely to be one of its accompaniments. But when all this is admitted, there can be no doubt that the war has stimulated an enormous amount of interest in questions of man's economic activity and achievements, both in their bearing on the war, to which they are seen to be all-important, and in their reaction on after-war problems.

Everyone to his taste. To some minds the most interesting economic result of the war has been its demonstration of the importance, at such a crisis, of the man who can do certain humble but useful jobs, and the effect on such folk of this proof of their importance with regard to their future claims on a bigger share of the good things of the earth. A war which produces a statement in the House of Commons that it is much easier to 
replace a Cabinet Minister than a good carter, must profoundly affect people's views concerning the value of the services rendered to the community by certain of its members, as compared with the prices paid for them. Prof. Todd, with the severe austerity of the true economist, confines his inquiry to the question of what he calls the Mechanism of Exchange, under which title he includes the whole machinery by which goods and services are exchanged between individuals and between nations. Economics he defines (somewhat elliptically) as the "Science of Exchange Values or the science of prices, which are exchange values expressed in terms of money"; and "money in the widest sense of the word, including metallic money, paper money, bankers' money, and the credit system, is the means of exchange." And so it follows that money is the standard of value, "the means by which the value of different things is measured against each other, just in the same way as the relative height or weight or age of things is measured . . . by describing them each in terms of certain accepted standards known as feet, pounds, or years." But the weak point of this monetary measure is that it is not constant like a foot or a pound weight. "The real value of money is its purchasing power . . . and as a matter of fact it is almost impossible to prevent that purchasing power of money varying from one place to another, and especially from one period to another. But such variation is fatal to the perfection of money as a standard of value. . . . During the last forty years the value of money as a whole has first fallen and then risen again very seriously, and the results have been sometimes disastrous and always very inconvenient." Has not the Professor put the facts the wrong way round in the last sentence? Forty years ago takes us to 1877 , and from that date to 1896 prices fell and the value of money rose, and since then the process has been contrariwise, as is shown by one of his own industriously prepared diagrams, which are an admirable feature of his book. Since, then, money has this weakness as a measure, "the character of money should be carefully studied so as to find out the nature of money, how it does its work, why these changes in its value take place, and, if possible, how to modify or prevent them ; and that is the underlying object of this book."

It is a great and inspiring subject that Prof. Todd has chosen and one that can be studied with especial profit in the fierce light that war's conflagration has thrown on it. $\mathrm{He}$ has brought to its elucidation much labour and industry and a considerable gift of exposition; and if one cannot altogether agree with all his 
conclusions, all his readers will thank him for gathering a store of facts concerning a problem of first-rate importance both during the war and in the future, when the joyful but difficult task of reconstruction will have to be faced.

It seems to me, though herein I differ with all diffidence from Professor Todd, that if there is one economic theory that the war has emphatically confirmed, it is the Quantity Theory, stated as follows by the Professor: "The general level of prices depends on the amount of money in circulation; it varies with the relation or proportion between the total amount of money in circulation and the total amount of goods or commodities in existence which must be exchanged for that money." This statement of the theory will probably be accepted by most people as roughly satisfactory, though each of us might wish to alter it in some small detail, and it leaves out, though Prof. Todd allows for it elsewhere, the important and elusive question of the velocity of circulation. Chapter XIII. is devoted to "The Test of the Quantity Theory," and opens with the question: "Is the Quantity Theory of Money true? Does the general level of prices depend on the amount of money in circulation, and, particularly, does it depend to any extent on the total gold supply or on the amount of gold in use as money?" In putting his problem thus, Prof. Todd sets a trap into which he himself afterwards walks. The Quantity Theory depends for its truth on the acceptance of all forms of money that is taken in payment for goods as equal in their effect on prices. If I buy a pair of boots and the bootmaker is prepared to take payment from me in a cheque, or a sovereign, or a Treasury Note, or silver, it does not matter which form of currency I use, when by handing it over I clear the boot-market of that pair of boots. Whether the volume of money depends on the volume of gold is a quite separate question, which does not affect the validity of the Quantity Theory. If gold were demonetised and were entirely and exactly replaced by paper, and the level of prices remained the same, the Quantity Theory would be not disproved, but confirmed. Much confusion has been produced before the war, and especially during its course, in discussions on the Quantity Theory and on Inflation, by this irrelevant entanglement of the relation between prices and the volume of gold; and Prof. Todd seems to have furthered this process of confusion. He finds that before the war there was, over a long course of years, a remarkable coincidence between the world's gold supply and the general level of prices. He thinks that this coincidence would be quite 
convincing "were it not for the difficulty of accepting the supposed supremacy of gold, in face of the fact . . . that gold itself, and indeed money of any kind, plays such an exceedingly small part in the enormous volume of the world's monetary transactions." What monetary transaction can take place without "money of any kind "? Apparently, by money the Professor is now talking of legal tender money; and again on the same page (p. 162) he speaks of "the amount of payments made by cheque, where no money passes," and yet on the first page of his book he has defined money (as quoted above) as including "paper money, bankers' money, and the credit system." Nothing baffles and exasperates the puzzled economic student so much as this habit of his teachers of using the terms of the science in different senses on different pages. Coming next to the experience of the war, Prof. Todd thinks that "at first sight they seem entirely incapable of any explanation which would be in the least consistent with the theory. For the facts are ... that the general level of prices has risen since the war beyond all experience in modern times, while the gold output has remained practically as it was before the war." So he is hoist with his own petard, being astonished at a huge rise in prices and no abnormal increase in gold, whereas if he had steadily regarded the total volume of accepted currency he would have found an increase in it bearing a striking enough relation to the rise in prices to confirm the Quantity Theory very handsomely. So he proceeds to account for the rise in prices by such items as labour cost; in other words, by saying that prices rose because they rose. However, he goes on to "theories afloat as to other causes, all of which do come within the scope of the Quantity Theory," such as the increased use of paper money and inflation of credit by Government financing of the war in the shape of War Loans, Treasury and Exchequer Bills [sic], etc." Prof. Todd believes that the first of these theories is disposed of by the fact that "the total increase of currency due to the issue of paper money was only some $£ 120,000,000$ up till the end of 1916," and he also observes that many of these Treasury Notes went abroad. "But," he proceeds, "even the total amount would probably not have been enough under present circumstances to produce any excess, for two reasons. In the first place, the circumstances of the war are in every way unique, and it is probable that one effect of the changes has been to make people use money in one form or another a great deal more than they formerly did." This is really a very curious argument. People use more money (which 
they could not do if more money had not been handed out to them) and consequently the fact that more money is used cannot be a cause of the rise in prices. "Finally," continues Prof. Todd, "it seems hard to believe that there could have been any marked rise of prices due to excessive issue of paper money (which is equivalent to the depreciation of the paper money) without there having been some disposition on the part of the public to prefer gold to paper, and any signs of such a tendency are entirely wanting either at home of abroad. The paper money has maintained its value absolutely, and that is not to be wondered at in view of the fact that the Treasury Notes are in the last resort convertible into gold at the Bank of England, though sensible and patriotic people have never shown the least desire to convert them, but have given up the gold habit completely, for the duration of the war at least." Here the Professor supplies his own answer. Patriotism and good sense have made people give up the gold habit, and so paper is king for the time being. But the statement that paper money has "maintained its value absolutely" will again confuse a student who remembers, in the first place, Prof. Todd's own statement that the value of money is its purchasing power; and, in the second, the great rise in prices which has diminished that purchasing power so seriously. One of the chief items in the excessive creation of currency during the war, namely, the increase in bank deposits through the planting of securities on the banks by the Government, is only referred to in a footnote to p. 170. Prof. Todd deals at greater length with the advances by bankers to customers against Government securities, but he thinks that this method of inflation has been adopted here to a comparatively slight extent. The increase of bank deposits he seems to ascribe to the increased value of our industrial output, due to the rise in prices. So, once more, there is more money because prices have risen, and therefore the rise in prices cannot be debited to the increase in money. "The long and the short of it is that no one can tell, and one opinion is worth no more than another on a question where the facts are not merely obscure, but almost unascertainable from their very nature." Such is the Professor's conclusion. To me, having had the benefit of reading Prof. Shield Nicholson's address to the Statistical Society on "Statistical Aspects of Inflation," it seems clear that there has been, as he therein stated, "an abnormal growth in the various kinds of currency as compared with the pre-war rates of increase," and "an abnormal rise in the prices of all the groups of commodities used for index 
numbers." It also seems clear, though I fully agree with Prof. Todd that on this difficult question one opinion is as good (or as bad) as another, that this general rise in prices could not have taken place without the increase in currency, because without it no increase in demand could have been "effective." And since Prof. Shield Nicholson also gives his authority to the view that "the root cause of the inflation of the currency has been the great expansion of Governmental credit," it is the practical duty of all who see the serious evils now being produced by this inflation, especially in its effect on the minds of the wage-earners, to press for sounder methods of war finance.

Hartley Withers

Peaceful Penetration. By A. D. McLaren, author of "An Australian in Germany," etc. (Constable. 1916. Pp. 224.)

Several books have been written during the last two years on "peaceful penetration" as understood and carried on by the Germans. Those of M. Henri Hauser, Professor Millioud, and Signor Preziosi, which were reviewed in this Journal in June, 1916, gave a fairly exhaustive survey of the nature of the German attempt to secure economic control of the world's business. Mr. McLaren has not much that is fresh to tell us about the operations carried out by Germany in European countries, but his account of the German colonial effort, especially in regard to Australasia, will probably be news to most of us in some respects, although the facts were, no doubt, already well known to many people in Australia and New Zealand. I am referring to the earlier schemes set on foot by the ingenious controllers of German Kolonialpolitik, not to the more recent manifestations of their activity, of which the state of the metal industry in Australia was a striking example, requiring drastic measures after the war began on the part of the Commonwealth Government. The public are well aware now that when the war broke out German agencies had control of the Broken Hill Mines, the Associated Smelters, and other industrial organisations in Australia, and that these concerns were bound by contract to confine the sale of their products to German agents. As Mr. McLaren puts it:"In practice 'control ' had worked out in this fashion-Great Britain paid $£ 90$ for spelter in America ; Germany paid $£ 30$ for spelter produced mainly from Australian ores." Long before the Germans secured "control" of Broken Hill, to possess colonies was a German aspiration. Before the German Empire came into being it was possible for a 